This is a self-archived version of an original article. This version may differ from the original in pagination and typographic details.

Author(s): Nousiainen, Tuula; Kangas, Marjaana; Rikala, Jenni; Vesisenaho, Mikko

Title: Teacher competencies in game-based pedagogy

Year: 2018

Version: Accepted version (Final draft)

Copyright: (c) 2018 Elsevier.

Rights: $C C B Y-N C-N D 4.0$

Rights url: https://creativecommons.org/licenses/by-nc-nd/4.0/

Please cite the original version:

Nousiainen, T., Kangas, M., Rikala, J., \& Vesisenaho, M. (2018). Teacher competencies in gamebased pedagogy. Teaching and Teacher Education, 74(August), 85-97.

https://doi.org/10.1016/j.tate.2018.04.012 


\title{
Teacher Competencies in Game-Based Pedagogy
}

\author{
Tuula Nousiainen $^{\mathrm{a}}$, Marjaana Kangas ${ }^{\mathrm{b}}$, Jenni Rikala $^{\mathrm{a}}$, Mikko Vesisenaho ${ }^{\mathrm{c}}$ \\ ${ }^{a}$ Finnish Institute for Educational Research, University of Jyväskylä, Finland \\ P.O. Box 35, FI-40014 University of Jyväskylä \\ tuula.j.nousiainen@jyu.fi \\ ${ }^{\mathrm{b}}$ Centre for Media Pedagogy, University of Lapland, Finland \\ P.O. Box 122, FI-96101 Rovaniemi \\ marjaana.kangas@ulapland.fi \\ ${ }^{c}$ Department of Teacher Education, University of Jyväskylä, Finland \\ P.O. Box 35, FI-40014 University of Jyväskylä \\ mikko.vesisenaho@jyu.fi
}

\section{Abstract}

This study examines what kind of competencies teachers need in using game-based pedagogy (GBP). In our conceptual framework, GBP entails four approaches: using educational games or entertainment games, learning by making games, and using gamification in learning. Our data, consisting of teachers' documentation, thematic interviews and questionnaires, were analysed using qualitative content analysis. Four main competence areas were identified: pedagogical, technological, collaborative and creative. The results are applicable for developing teacher education and in-service training, as teacher competencies in game-based learning will be more integral to teachers' professional knowledge and skill repertoires.

Keywords: Teacher Competence, Game-based Pedagogy, Case Study, Basic Education, Primary School, Educational Technology

\section{Introduction}

Novel technologies and games play an increasing role in twenty-first century education (Van Eck, 2006; Kapp, 2012). In a digitalised society with renewed curricula, meaningful integration of new tools and technology into teaching and learning depends on teachers' ability to a) structure the learning environment in new ways, b) merge new technology with a new pedagogy and c) develop socially active classrooms encouraging cooperative interaction, collaborative learning and group work (UNESCO, 2011). This requires broad management skills and teacher roles.

In game-based learning, teachers play important roles in enhancing the learning and motivational aspects and in designing game-based learning processes (Kangas, Koskinen, \& Krokfors, 2016; Shah 
$\&$ Foster, 2015). These perspectives are emphasised in many studies that present pedagogical frameworks designed for integrating games into classrooms. Sørensen (2011) introduces the concept of educational design that includes learning objectives, the selection of subject-related content, planning, and the organisation of learning processes in game-based learning. Foster and Shah (2015) present the Play Curricular activity Reflection Discussion (PCaRD) in which the teacher is an agent who connects game-based learning to curriculum. Kangas et al. (2016) found that teachers' pedagogical activities are evident in various game-based learning processes: in planning, in orientation, during the gaming, and after the game-play sessions. These phases are also included in a pedagogical model of creative and playful learning designed for applying play and games in teaching (Kangas, 2010b). As earlier research shows, the teacher's role can vary from a leader to a facilitator and from an organiser and planner of learning processes to a guide and a tutor during the game-play sessions, depending on the learning goals and the game context (Hanghøj \& Brund, 2011; Kangas et al., 2016).

However, teachers have been underrepresented in game-based learning literature and comprehensive approaches to teachers' competencies in game-based pedagogy (GBP) are rare (Foster, Shah, \& Duvall, 2015; Hwang \& Wu, 2012). In addition, most approaches still assume that game-based learning's effectiveness is solely due to the game effect (Foster et al., 2015; Young et al., 2012). As it has been acknowledged, technologies and games do not guarantee meaningful learning experiences (Löfström \& Nevgi, 2007); much depends on teachers' pedagogical practices (Rikala, 2015), knowledge, skills (Shah \& Foster, 2015), personal interest and pedagogical and emotional engagement (Kangas, Siklander, Randolph, \& Ruokamo, 2017). An approach is needed where the effect of game-based learning is studied while also considering teachers' competencies and roles, the game-based pedagogical process and the context the game is integrated into (Foster et al., 2015; Kangas et al., 2016). Earlier research has shown that sound pedagogical models to follow, as well as relevant teacher competencies, are important for successfully implementing GBP (Barab, Gresalfi, \& Ingram-Goble, 2010; EgenfeldtNielsen, 2005; Hamari \& Nousiainen, 2015; Meyer \& Holm Sørensen, 2011; Shah \& Foster, 2015; Williamson, 2009).

The aim of this paper is to identify possible competence areas teachers need in GBP. The study focuses on the basic education context entailing both primary and lower secondary school, considering teacher competencies and GBP in a broad pedagogical perspective, including teachers' activities in actual teaching practices and processes - before, during and after game play inside/outside the classroom (cf. Kangas et al., 2016). We combine an earlier pedagogical model of creative and playful learning (Kangas, 2010b) and four game-based approaches (Nousiainen, Vesisenaho, \& Eskelinen, 2015) into a conceptual and pedagogical framework for examining teacher competence areas in GBP. Our focus entails nondigital learning environments as well as digital games. Based on authentic implementations of GBP, we aim to answer the research question: What kind of competencies do teachers need in using different game-based pedagogical approaches?

\section{Theoretical Background}

The study consists of two key concepts: game-based pedagogy (the context for the research) and teacher competence (the investigated phenomenon). 


\subsection{Game-Based Pedagogy}

In our study, we define GBP as a pedagogy that is grounded on different implementations of four gamebased approaches (Nousiainen et al., 2015): using educational games, using entertainment games, learning by making games, and using game elements in non-game contexts (i.e. gamification). The definition encompasses GBP both in digital and nondigital contexts. The first three approaches are based on Van Eck's (2006) definition of game-based learning, while gamification has more recently become prevalent as a separate concept (e.g. Deterding, Dixon, Khaled, \& Nacke, 2011; Kapp, 2012). In this categorisation (Figure 1), 'playfulness' is defined as a mindset and stance that cross-cuts all game-based approaches.

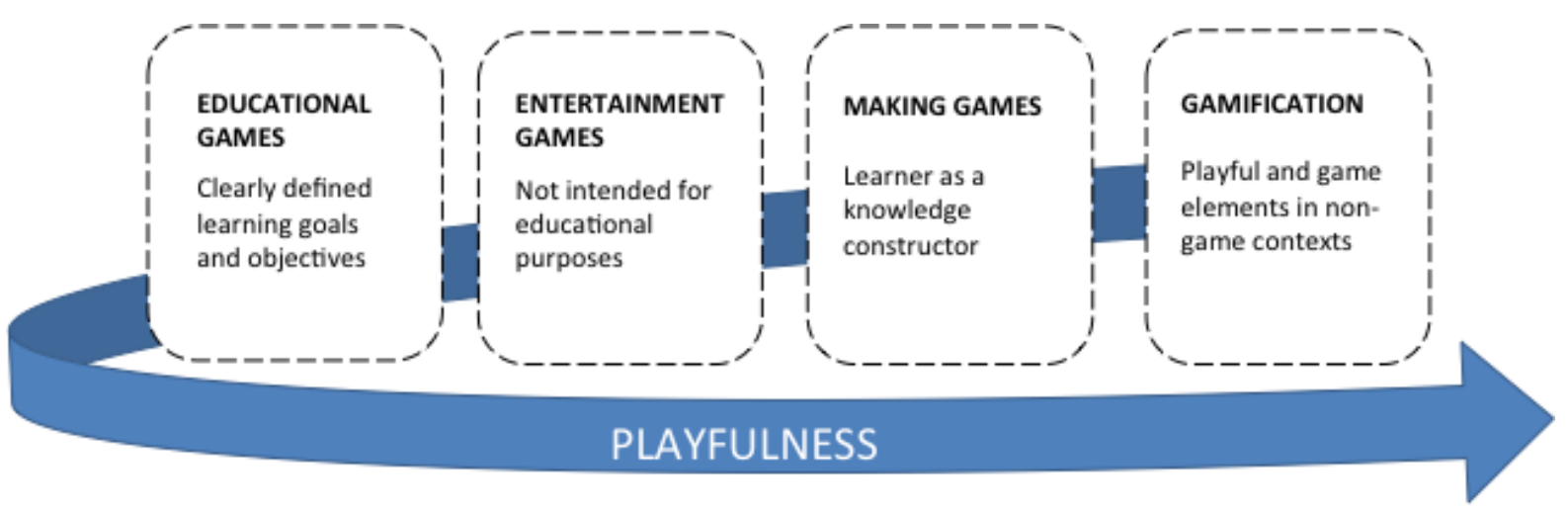

Figure 1. Game-based pedagogical approaches.

In practice, different GBP approaches often coexist and overlap. For example, a learning project might be based on a fictional narrative where one task involves solving a mystery within an entertainment game, another involves demonstrating a specific skill in an educational game, and yet another requires creating a challenge for peers by making a small game using a game-creation tool.

Educational games, designed to address specific learning objectives and support the learner in reaching certain outcomes (De Freitas, 2006; Dondi \& Moretti, 2007), are often the most approachable way of bringing GBP into teachers' practices. They also lend themselves to study of their effectiveness; much research focuses on the learning effects of particular educational games. Positive learning outcomes and experiences have been found, for example, in science (Corredor, Gaydos, \& Squire, 2014; Squire \& Jan, 2007), mathematics (Kebritchi, Hirumi, \& Bai, 2010; Shin, Sutherland, Norris, \& Soloway, 2012), literacy learning (Richardson \& Lyytinen, 2014), collaboration (Hämäläinen \& Oksanen, 2014), and the self and identity (Chee \& Tan, 2012). Usually, games are brought into class to enhance learners' motivation, but the motivational effects of educational games do not necessarily last beyond initial novelty (Ronimus, Kujala, Tolvanen, \& Lyytinen, 2014). Another challenge relates to whether the learning content is adequately integrated with the game mechanics and to what extent the game supports the learner in focusing on aspects essential for learning (Devlin, 2011; Egenfeldt-Nielsen, 2011). Consequently, promoting game-based learning at school can be sustained, according to Shah and Foster (2015), in cases where teachers' knowledge of games and their curricular relevance is sufficient.

An alternative approach is to build on the inherently motivating nature of entertainment games, not primarily intended for educational purposes and therefore requiring more from the teacher, as there is 
no built-in pedagogical content, and the existing content may sometimes be incorrect or misleading (Van Eck, 2006). Yet entertainment games lend themselves to flexible use, so with innovative ways of applying and integrating them with other practices, they can be useful (Van Eck, 2006). Teachers must attune learners to what is important within the game and support their learning beyond the immediate game design (Gresalfi, Barnes, \& Pettyjohn, 2011). With additional activities complementing the game play, the game world and narrative can be expanded beyond the game itself (Charsky \& Mims, 2008; Van Eck, 2006). Entertainment games have also been used as part of broader playful or gamified activities where their role is to provide a narrative context, challenge, or mystery in which the learners engage (Nousiainen et al., 2015).

The third approach to implementing GBP is learning by making games (Kangas, 2010a; Vos, van der Meijden, \& Denessen, 2011; Yang \& Chang, 2013). One goal is enhancing students' understanding of specific learning content; thus, when designing and building a game - as opposed to merely playing one - the learner must effectively construct new relationships with knowledge and learn new things (Kafai, 2006). Game design forces students to solve problems and consider things from different viewpoints (Kangas, 2010a; Randolph, Kangas, Ruokamo, \& Hyvönen, 2016). Thus it has recently also been closely connected to the development of learners' key competencies such as thinking skills, ICT competencies, communication and creative expression (Hayes \& Games, 2008; Kafai \& Resnick, 1996; Kangas, 2010a, 2010b; Pelletier, Burn, \& Buckingham, 2010; Robertson, 2012; Yang \& Chang, 2013). Key competencies or twenty-first century skills (Binkley et al., 2012; European Commission, 2018) refer to broad skills and competencies students need in the rapidly changing world, and there is a current significant educational shift towards them (Caena, 2014).

The fourth approach, gamification, turns a non-game activity into a game to make it more attractive and motivating (Deterding et al., 2011; Farber, 2015; Stenroos, 2015). Game thinking and game elements engage learners (Deterding et al., 2011; Kapp, 2012) and effectively extend learning (Farber, 2015), supporting its cognitive, emotional, or social dimensions, particularly the latter two (Dominguez et al., 2013; Lee \& Hammer, 2011). In practice, gamification takes a wide range of forms from simple 'pointification' to activities consisting of different game-like, narrative and playful elements, often crossing borders between subjects and grade levels (Farber, 2015; Nousiainen et al., 2015). Typical examples of gamification include rewards, points, badges and leaderboards (Farber, 2015; Stenroos, 2015). However, it is problematic to use gamification in school contexts merely as a reward system or understand it in terms of mechanics, neglecting other elements more important to the learner's motivation, engagement and experience (such as storytelling, character development, challenge and problem solving) (Farber, 2015; Kapp, 2012). It is thus justified to ponder whether to focus on using 'fun' created by game-like interaction to make simple tasks rewarding (Stenroos, 2015; McGonigal 2011) or to strive to promote interest and engagement in learning goals through game-based activities.

Playfulness is central in creating intrinsically motivating games where the activity is experienced as enjoyable and worthwhile for its own sake (Bateson \& Martin, 2013; Csikszentmihalyi, 1993; Stenroos, 2015). In the educational context, playfulness is important in learning (Kangas, 2010b; Resnick, 2006) as it can increase the likelihood of creative results (Amabile, 1983), creating common ground for collaborative learning and enhancing students' satisfaction with the learning environment (Randolph et al., 2016). The term playful learning has been used to refer to learning embedded with playful engagement and creative game creation and gameplay in technology-enhanced learning environments (Kangas et al., 2017). 


\subsection{Teachers' Competencies}

In this study, teacher competence is understood as a multi-layered concept comprising cognitive, skillbased and affective components - knowledge, skills, attitudes, values and ethics (Binkley et al., 2012; European Commission, 2018; Spencer \& Spencer, 1993). These layers mean individuals should have some theoretical background knowledge of each educational topic, the practical skills to apply this knowledge effectively and a certain attitude and stance (characteristics such as openness, responsiveness, persistence and ability to see failures and mistakes as learning opportunities) (Binkley et al., 2012). In GBP context, the teacher needs knowledge about the subject matter, methods of teaching and how to integrate different game approaches into teaching and learning (cf. Koehler \& Mishra, 2009).

In addition, in this study, teacher competence is defined as a context-bound and process-oriented concept (cf. Caena, 2014), depending on the learning environment and contextual factors such as learning goals, social environment and resources. This means that teacher competence involves professional, personal and contextual elements, integrating personal characteristics, knowledge, skills and attitudes needed for effective teaching in different contexts (Bjarnadottir, 2005; Tigelaar, Dolmans, Wolfhagen, \& Van Der Vleuten, 2004). Teachers are also expected to have digital competencies (Redecker, 2017; Johannesen, Øgrim, \& Giæver, 2014).

In GBP, teacher competencies encompass different digital and nondigital game-based learning approaches. So far, research has mainly focused on identifying aspects influencing the adoption of digital game-based learning among teachers (e.g. Bourgonjon et al., 2013; De Grove, Bourgonjon, \& Van Looy, 2012; Hamari \& Nousiainen et al., 2015; Ketelhut \& Schifter, 2011). Issues affecting the use of digital game-based approaches include, for example, openness towards new technologies, supportive organisational culture, digital self-efficacy and the compatibility of technology with one's teaching (Hamari \& Nousiainen, 2015). Variables such as motivation, confidence, knowledge about general game use, knowledge about using games to implement different teaching methods and knowledge about using games to implement pedagogical strategies for teaching subject matter also impact and predict teachers' adoption of game-based teaching approaches (Hsu, Tsai, Chang, \& Liang, 2017).

Teachers know their roles have changed in using new technologies and digital games, but lacking necessary competencies and training, are unsure how to adopt these changes (Allsop \& Jessel, 2015). Hanghøj and Brund (2011) describe four teacher roles related to GBP: instructor, playmaker, guide and evaluator. Instructor involves planning and communication; the playmaker denotes competencies in communicating tasks, roles, goals and dynamics of the current game. The guide supports or scaffolds students during gameplay, and the evaluator understands, explores and provides dialogical response to students' gameplay experiences (Hanghøj, 2013; Hanghøj \& Brund, 2011). Other teacher roles acknowledged in the literature include the planner of pedagogical entities, organiser, mentor, tutor, facilitator, leader and co-learner (Kangas et al., 2016). Teachers' experience and awareness of the curriculum-relatedness of games is also crucial (De Grove et al., 2012). In addition, teachers require game-specific knowledge and ability to analyse a game's technology, pedagogy and content to determine its usefulness in education (Hanghøj \& Brund, 2011; Shah \& Foster, 2015). 


\section{Methodology}

\subsection{Research Context}

The study was conducted with 15 schools and their partner schools in Southern Finland, participating in a specific networking project on GBP during 2013-2016. Primary grades (6-12-year-olds) were taught in 14 schools, and lower secondary grades (up to 16 years of age) were taught in six schools. School sizes ranged from under 200 students to over 600. In each, two or three teachers were core participants who then further disseminated their experiences to other teachers in their respective schools and networks. On average, thirty active teachers participated; the exact number varied, as some moved to different schools at mid-project. The participants volunteered to take part in the project based on their interest in GBP; their prior experience did not play a role in the project, as the study did not focus on examining individual teachers' digital skills or experience with games. The majority of the participants (approximately 75\%) were class teachers in primary school and the rest taught specific subjects (e.g. ICT, languages, mathematics) in lower secondary school.

Teachers and headmasters created school-specific plans for applying GBP to address particular pedagogical goals, interests and challenges. First, they assessed the GBP competence profile of their school by evaluating on a scale of 1 to 10 how much collective experience and expertise there already was in the school in terms of different GBP approaches, and indicated which of these approaches they intended to focus on during the project. Based on this analysis, teachers drafted their plans for implementing GBP in authentic teaching/learning situations with students. The project provided digital devices and game applications, training on game-based tools and methods as well as platforms for sharing and networking both face-to-face and online. In addition to regular joint training events, individual schools could invite experts to train their teachers on topics particularly interesting or relevant to them (such as commercial game applications, role playing and game programming).

\subsection{Data Collection}

To examine teacher competencies in authentic, real-life contexts, we employed a case study approach. Case studies are suitable especially when boundaries are unclear between phenomenon and context (Yin, 2003). One main advantage of this approach is its ability to provide and manage different types of data, ranging from documents to interviews and observational data (Hammersley \& Gomm, 2000; Yin, 2003). Qualitative and quantitative data were collected throughout the project; we focus on qualitative data related to the teacher perspective (Table 1).

Table 1. Description of data

\begin{tabular}{|l|l|}
\hline Type of data & Description \\
\hline Documents & $\begin{array}{l}\text { Blog entries, digital portfolios and activity descriptions written by teachers } \\
\text { (2013-2016) }\end{array}$ \\
\hline Interviews & $\begin{array}{c}\text { Thematic interviews with teachers (N=6) conducted in 2014. } \\
\text { School 1: Teacher 1 (teaching all subjects to Grades 2-3) and Teacher 2 } \\
\text { (teaching all subjects to Grades 4-5) }\end{array}$ \\
\hline
\end{tabular}




\begin{tabular}{|l|l|}
\hline & $\begin{array}{l}\text { - School 2: Teachers } 3 \text { and 4 (both teaching all subjects to Grade 5) } \\
\text { - School 3: Teacher 5 (teaching all subjects to Grade 6) } \\
\end{array}$ \\
\hline Questionnaires & $\begin{array}{l}\text { Openool 4: Teacher 6 (teaching math and ICT to Grades 7-9) } \\
(\mathrm{N}=12)\end{array}$ \\
\hline
\end{tabular}

Teachers' documents provided overviews of all game-based activities occurring in the schools and teachers' reflections on them. The interviews with six teachers (see Table 1) delved into their projects and practices in more depth, exploring the teachers' and students' experiences related to the GBP activities implemented in the school (see Appendix). The interviewees were selected based on two main criteria. Firstly, the sample was intended to be as representative of the participants as possible: the interviewed teachers came from three primary schools and one lower secondary school, the grade levels they taught ranged from Grade 2 to Grade 9, and along with five teachers from Finnish-speaking schools, we interviewed one teacher from a Swedish-speaking school. Secondly, we wanted to interview teachers who could offer insights into different GBP approaches, from the use of existing educational or entertainment games to broader gamification efforts and game-making activities. Thus, with the aid of the coordinator of the networking project, we identified a combination of schools and teachers with somewhat different profiles in terms of the GBP approaches on which they were principally focusing. The questionnaires, which were sent to all teachers participating in the project and focused on the same topics as the interviews (see Appendix), supported the documents and interviews by corroborating or complementing the insights provided by them. They included both quantitative Likert-scale items and open-ended questions. In this paper, we only use the latter.

The language of the data was Finnish or, in a few cases, Swedish. The analysis was conducted in the original languages, and excerpts included in this paper were translated by the authors.

\subsection{Analysis}

The interviews were transcribed, and the whole data set was analysed using qualitative content analysis conducted iteratively by the researchers. The analysis began with a data overview during which we identified all references to competencies without yet differentiating them according to more specific criteria. Altogether, we found 232 relevant quotations - descriptions of actions, feelings or reflections related to teacher competencies. As a unit of analysis, we used a quotation, varying from one sentence to a multi-paragraph excerpt.

Next we classified the quotations according to content categories, using a data-driven approach and an open coding procedure without imposing a predetermined set of categories on the data. During this process, some quotations were discarded as too vague or ambiguous. The first cycle of this phase produced seven categories, sorted into four higher-level categories or competence areas. The subcategories were reviewed again, with some further divided, so our final classification included ten subcategories under four main categories (see Table 2 in Section 4).

We also sorted quotations according to different GBP approaches and different pedagogical process phases. As an analytical tool, we applied a conceptual and pedagogical framework for game-based learning (Figure 2), based on two pedagogical models — creative and playful learning (Kangas, 2010a) 
and participative game pedagogy (Krokfors, Kangas, \& Kopisto, 2014) - and the GBP approaches presented in Figure 1.

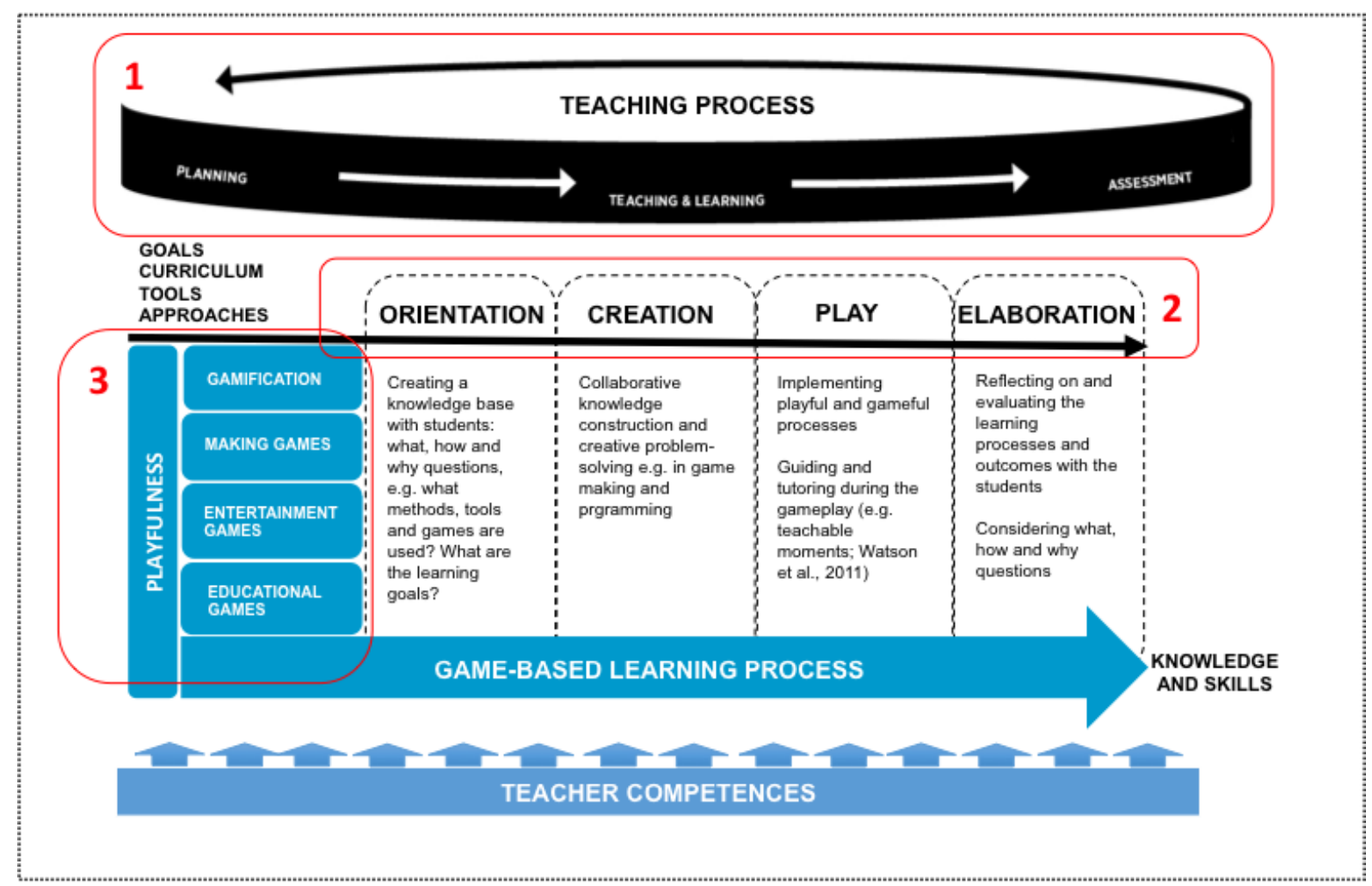

Figure 2. Conceptual and pedagogical framework for game-based learning.

The teaching process (marked with \#1 in Figure 2) comprises initial planning, teaching and assessment. The actual game-based learning process in which students have an active role (\#2) is divided into four phases: orientation, creation, play and elaboration. Within each competence area, we identified learning activities corresponding to specific phases of the process. Also, to the extent possible based on the data, we mapped competencies to specific game-based pedagogical approaches (\#3). The framework is useful in the analysis process and provides tools for designing teaching based on GBP. Guiding questions (Figure 2) in the orientation and elaboration phases may help teachers involve students in the iterative design and assessment of game-based activities.

\section{Findings: Areas of Teacher Competence}

Implementing GBP in widely ranging ways necessitates varied competencies. The teachers reported that they had used all four GBP approaches (Figure 1) in their projects, with educational games most common. Over $80 \%$ of the teachers had used educational games at least somewhat extensively, and almost $60 \%$ had at least sometimes done game-making activities with their students (see Nousiainen et al., 2015). Approximately 40\% had at least sometimes used gamification or entertainment games with their students (Nousiainen et al., 2015). In our analysis, gamification was implemented in two ways: role-play activities and the use of points and rewards. Implementations of GBP varied from activities related to one subject to gamifying nearly all classroom activity. Not every activity followed strict 
game-like rules and structures; some learning processes consisted of general playful elements to motivate students.

Based on our data, we identified four main areas (pedagogical, technological, collaborative and creative; Table 2) and ten sub-areas of teacher competence.

Table 2. Areas of competence in game-based pedagogy

\begin{tabular}{|c|c|c|c|}
\hline 1. Pedagogical & 2. Technological & 3. Collaborative & 4. Creative \\
\hline $\begin{array}{l}\text { 1.1 Curriculum-based } \\
\text { planning } \\
\text { 1.2 Tutoring } \\
\text { 1.3 Assessment }\end{array}$ & $\begin{array}{l}\text { 2.1 Analysing games } \\
\text { and technological tools } \\
\text { 2.2 Overcoming } \\
\text { technology-related } \\
\text { obstacles }\end{array}$ & $\begin{array}{l}\text { 3.1 Sharing and co- } \\
\text { development within } \\
\text { the school } \\
\text { 3.2 Networking and } \\
\text { collaboration beyond } \\
\text { the school }\end{array}$ & $\begin{array}{l}\text { 4.1 Playful stance } \\
4.2 \text { Ability to explore } \\
\text { and improvise } \\
\text { 4.3 Creative } \\
\text { orientation to self- } \\
\text { development }\end{array}$ \\
\hline
\end{tabular}

\subsection{Pedagogical Area}

Teachers regarded it essential that they have enough pedagogical competencies in using different gamebased approaches in their teaching. Teachers' reflections revealed three sub-areas that refer to competencies involved in making pedagogical choices throughout the process of teaching and learning: 1) curriculum-based planning, 2) tutoring and 3) assessment competencies.

\subsubsection{Curriculum-based planning}

First, teachers need competencies related to planning meaningful game-based activities within the curriculum. They discussed the importance of meaningfully implementing GBP, where one main competence emerging from their reflections was the ability to apply GBP to support the curriculum. This entailed understanding the strengths and limitations of conveying curricular contents with different game-based approaches. For example, extensive role-playing projects may engage learners in understanding wider learning goals from different perspectives but may not be ideal for learning specific subject-based details, as stated in Excerpt 1 related to gamifying the contents of sixth-grade history. Yet the case may be the opposite when using, or having students create, game-based quizzes or similar products.

(1) And of course, like always, the starting point of planning a game, or gamification, is the curriculum. That's where the contents come from. It's just... the contents are transformed into a game-based format. ... It's probably not like they will remember any specific dates [from history] — the students, I mean, that they would remember some specific detail... but that's not what the purpose is. [Primary school teacher] 
Another dimension of curriculum-based planning is the competence to involve students in defining and formulating curriculum-related goals, helping them orient to these goals (i.e. orientation in Figure 2). For example, teachers defined broad goals for students' activity while allowing them participative roles in planning more specific methods and learning contents. Excerpt 2 provides an example of involving fifth-graders in designing game-based activities for second-graders. The learning process included both game-making and gamification activities in the context of a space-related adventure. The excerpt illustrates how teachers can support students' agency in planning game-based learning, for example, by allowing them to review the curriculum content to integrate it into a narrative frame.

(2) First, [the students] were space agent cadets, and after that, our planet/galaxy has been threatened by different threats, and we have been solving them so that we've always consulted the curriculum to see what second-graders have recently been studying. And related to those topics, fifth-graders have organised different kinds of activity points, and that way, we have structured... kind of driven the story forward. [Primary school teacher]

Teachers also regarded important to have the ability to plan game-based activities for supporting students' academic learning and broader key competencies. Excerpt 3 describes how the teacher intended to use games and gamification to tap into subject-specific objectives and collaborative problem-solving skills.

(3) I would think, at least, that the experientiality that comes with [games and gamification] and cooperation, collaboration, and problem solving - would also make the content more accessible, and the learning ... would be deeper. [Primary school teacher]

\subsubsection{Tutoring}

Second, teachers reflected that tutoring competencies are needed. Tutoring competencies refer to guiding the learning process during game-based activities, including applying motivational techniques, personalising activities and flexibly regulating the degree of student responsibility. One main competence emerging from the data was supporting learners' agency and self-regulation, emphasised especially in broader gamified projects and in making games. In Excerpt 4, a teacher discusses learning to give the students more authority and responsibility during the game-based process, which in this case focused on making games.

(4) The emphasis has been especially on [the students] doing things for themselves and also taking responsibility. And you learn to give responsibility - that's another aspect in it. The degree of responsibility can be adjusted very well by the teacher. [Primary school teacher]

In Excerpt 5, another teacher describes how his class conducted role-play-based projects in geography and history, the learning themes being related, respectively, to different countries and to life in the Middle Ages. In these gamified activities, students self-directedly worked on game-based tasks and produced a final artefact demonstrating their learning. The teacher presented a variety of options for doing this, and the students chose their preferred method.

(5) [Students] have had quite a lot of freedom in planning the final outputs of these game-based projects. Basically, it hasn't mattered to us what the output is. Is it a video, is it a 
presentation, is it a game, is it some kind of booklet? They've been free to reflect on what their particular strengths are. ... We've been demoing Kodu and Minecraft, and some iPad apps, too, to all students - how one can make final outputs with them - and they have all made [final outputs] on a very broad spectrum. [Primary school teacher]

If the students worked in a self-directed manner, the teacher's tutoring role was to observe the activities, ensure nobody got stuck and ensure the students' work stayed within the general pedagogical frames for the activity. It was crucial that the teacher identify and react to teachable moments (cf. Watson, Mong, \& Harris, 2011), for example by providing relevant information when needed. For instance, in the history project, students spontaneously started trading goods and services with each other, opening up an opportunity for discussing the economic and social structures in medieval communities. Yet in some cases, the regulation of responsibility meant it was necessary to make the process more structured. This issue arose mainly when using existing games or game-creation tools; sometimes the teacher had to recognise when it was necessary to restrict time spent playing an educational game to prevent students losing concentration and becoming bored, while in other cases, teachers had to be able to decide when more structure was needed to direct the students' excitement towards the main points of the learning process.

Findings indicate that teachers also need to be able to support individual learning trajectories and personalised learning in GBP; this requires understanding the characteristics and affordances of different game-based approaches to facilitate learning. According to the data, sometimes the most straightforward way to support personalised learning was using educational games where the fastest learners could independently proceed further, while those struggling with learning were motivated to practice more. On the other hand, teachers felt that in broader gamified projects they could support individual learning trajectories by allowing students to demonstrate their learning in multiple ways (see Excerpt 5), depending on the learning goals.

\subsubsection{Assessment}

Third are assessment-related competencies, involving both assessing students' learning and reflecting with them on the process. Based on data, one important competence was the ability to collect meaningful evidence from game-based activities as the basis for efficient assessment. Games can provide teachers with plenty of data to support assessment but the teacher needs the competence to utilise this data efficiently, as explained in Excerpt 6 by a teacher who elaborates on this from the perspective of using an educational math game, Sumdog.

(6) And then again, if I go back to those simpler tools like Sumdog, for example... it tells you directly what the student knows and where they still need some more practice. What percentage [of the tasks] they get right, and so on. [Primary school teacher]

The challenging nature of assessment manifested especially in the gamification of learning processes. In Excerpt 7, this is discussed by two teachers whose fifth-graders have participated in various types of gamified activities, sometimes also planning such activities for younger students. The teachers address the need to observe the process comprehensively, including both subject-related content and students' key competencies, to identify different ways in which students may demonstrate their learning during the activity. Another point mentioned is the need to know ways to provide less active students with opportunities to make their skills visible. 
(7) Teacher 1: So, I don't know, maybe [during the process] you can better assess how active and how interested the students are, and what their interaction skills are like. Kind of general [skills] like that. On the other hand, some surprising skills may also emerge in some students, which are not revealed in normal classroom situations, and that can, of course, affect assessment just as much. And why not, if someone turns out to have more skills than he/she [normally] shows?

Teacher 2: $\quad$ In some situations, it might be useful if someone could develop a good, kind of, set of assessment criteria. Like how to observe the students' activities in a game-based process. ... What kinds of roles appear in those situations? And are some [students] left out? How to assess someone who doesn't necessarily participate so much?

Researcher: $\quad M m$, that's a really good point.

Teacher 2: $\quad$ Like, for example, the teacher can give those students ... observer's tasks or other kinds of tasks.... And it's not inferior in any way to those who participate [more actively].

Researcher: Everyone gets to use their own strengths?

Teacher 2: $\quad$ Yeah, yeah, it's quite an applied effort, I think, the assessment. Of course, you have the specific products and tasks you can look at, and those are easy to evaluate. But evaluating the process... there you need to have a kind of comprehensive understanding about it, because there are so many elements which you can assess.

The discussion illustrates that in a broad gamification approach where the activity stretches over a long period - even the whole school year - the collection of process-related data is especially important. The teacher should be able to envision the kind of evidence needed for assessment purposes and plan how the game-based activity produces this evidence. This necessitates the ability to form a clear overall picture of the whole activity as well as some knowledge about learners' roles in game-based processes to enable personalisation in the assessment phase. Teachers emphasised, for example, the need to know how to establish intermediate checkpoints or milestones to avoid having to look back at the whole process at once.

Competencies supporting students' agency are also related to assessment. Teachers mentioned the importance of evaluating activities and reflecting on the learning process with the learners themselves (i.e. elaboration in Figure 2); for example, discussing whether the students felt like they learned the same things through game-based activities as they would have learned from books.

\subsection{Technological Area}

The results also show that competencies related to technological areas are important in order to implement GBP. Two aspects of technology-related competencies were identified: 1) analysing games and technological tools and 2) overcoming technology-related obstacles. 


\subsubsection{Analysing games and technological tools}

The teachers referred to issues related to the ability to analyse games and technological tools to select and combine them with nondigital tools in pedagogically meaningful ways. This means that teachers may have to look beyond the most obvious, easily accessible alternatives. This in turn requires prior knowledge of available tools and means of accessing additional resources. However, sometimes ideal solutions are found only after less successful attempts; therefore, readiness to continuously evaluate and reassess tools is required. In Excerpt 8, a teacher critically reflects on choices he previously made, and based on experience gained from this game-based project, considers what kinds of games are suitable for maths.

(8) Well, [previously] I probably didn't pick games that were so suitable pedagogically. In maths, you [should have] games which help [the students] learn well and help the students to understand exactly what they are doing. Some drill exercises can also [be done] on the laptop, but they are sometimes pretty boring to do - but if it's in the form of a game, then it might be a bit more [interesting]. [Lower secondary school teacher]

\subsubsection{Overcoming technology-related obstacles}

Teachers acknowledged that problems using digital tools were sometimes encountered and reported experiencing a lack of technological competence and a need to learn more. Therefore, the ability to flexibly overcome technology-related obstacles emerged as another important competence. Teachers sometimes faced difficulties trying to prepare devices and applications in advance to ensure a problemfree learning process; often, a cycle of trial and error was required to find working solutions.

Even if a teacher tries to prepare as carefully as possible to use technological tools, difficulties may emerge during game-based activities, so the teacher needs the competence to devise an alternative plan quickly in case some activities cannot be conducted as intended. Advance preparation of Plan B is useful, yet it will often be necessary to improvise and modify the goals and tools during the process. The more alternative tools the teacher knows, the less the learning process will be derailed by technological problems. One particular difficulty was the uncertainty related to identifying when a problem was solvable by the teacher on the spot and when it was not (e.g. a problem with the wireless network, a missing component such as a SIM card or a device malfunction). As mentioned in Excerpt 9, however, one teacher alone cannot solve everything.

(9) When the network or the devices don't work, the students get frustrated quite quickly if they aren't able to do [their tasks]. One teacher alone can't always simultaneously solve problems and come up with other things to do in case the original plan can't be followed. [Primary school teacher]

Thus, competence to overcome technical problems entails knowing where to look for answers and who to ask for help. Being aware of relevant online resources (e.g. video tutorials and online communities), attempting different solutions despite uncertainty of their workability and not hesitating to involve colleagues and students in problem solving were seen as part of this competence. Teachers discussed how they sometimes avoid novel tools, feeling they have not sufficiently mastered their use, but they also mentioned practices where hands-on collaboration between teachers worked well in boosting 
confidence and competence in GBP. Clearly, the technological competence area is closely linked with the collaborative and creative areas.

\subsection{Collaborative Area}

The third area that emerged from the data entailed collaborative competencies in the context of GBP. This area relates to teachers' ability and readiness to share and communicate content, ideas, practices and technological know-how. Collaboration is required to introduce GBP into school culture and especially to make it a sustainable practice. This area emerged in our data at two levels. First, applying GBP requires support by the school; second, collaboration beyond one's own school was also discussed.

\subsubsection{Sharing and co-development within the school}

According to our data, teachers still have much to learn regarding mutual sharing of practices and ideas. They discussed what was required for sharing to become routine and what potentially hindered it. Despite their doing an increasing amount of teamwork, the ability and willingness to share was considered an area for improvement. As means to improve collaborative competencies, the teachers emphasised mutual support, joint idea creation and demonstration of concrete practices (Excerpt 10).

(10) I think the key [to encouraging other teachers to try GBP] is to engage them, like 'Let's do this thing together and see what we can come up with.' ... If you only give a ... lecture on what you have done, the other teacher will certainly feel a bit left out. [Primary school teacher]

Based on their experiences, key points in enhancing these skills included openness to new approaches, hands-on collaboration by co-developing something with experienced teachers, identifying hidden know-how among teachers and developing new solutions and conventions for sharing ideas and materials (e.g. with the aid of digital technology).

\subsubsection{Competencies for networking and collaboration beyond the school}

The teachers also mentioned extending collaboration beyond one's own school and exploring opportunities for sharing and co-development with teachers from other schools (see Excerpt 11). Crossschool collaboration necessitates adopting a broader culture of sharing and willingness to accept challenges. Like within-school collaboration, sharing with teachers from other schools takes various forms. The more concrete the collaboration, the more rewarding it was considered; to develop one's competencies, a joint project and/or participant observation in another school bore more fruit than merely listening to or reading about what others did.

(11) We networked, and now we have a joint game between [four schools]. And we are thinking about what we could do together at some point so that we'd get more students [involved]. We, the teachers, are going to go and visit different schools, and different students and teachers. [Primary school teacher]

Especially gamification had become more widely used during the project, as it spread from a small group of teachers to colleagues within and beyond the school (see also Nousiainen et al., 2015). For 
schools in our study, participation in a joint networking project facilitated collaboration and crosspollination across schools but valuable ideas and partners could also be found through online professional communities.

\subsection{Creative Area}

The final competence category is the creative area. In our data, this competence manifested as the ability to take a playful stance, explore and improvise and as the teacher's creative orientation towards selfdevelopment.

\subsubsection{Playful stance}

Playful stance manifested as the ability to see playfulness in almost any learning activity. The teachers discussed the notion of having a worldview where anything can be turned into a game by using game mechanics to engage learners. This was mentioned especially by teachers with a personal interest in gaming, role playing or storytelling, who felt motivated by inventing new game-based elements in their teaching - but it was not limited only to them. Some teachers noted that school inherently includes many aspects which can be considered gamification, even though teachers do not necessarily view them that way, and that teachers can start making their teaching more playful and developing gameful thinking just by building on these existing characteristics. In Excerpt 12, a teacher discusses beginning a learning task with a funny role play, providing a playful context for the students' work.

(12) You can turn everything into a challenge, or a story, or anything. ... And because games are always built on a story, so I think you just... You can just start a lesson like, for example, I rubbed some red paint or something on my face and came in through the door like, 'Nooo, I'm not [teacher's name], I'm [a] brain researcher, and I've forgotten everything I was supposed to lecture you about the brain. So you have to research for yourselves!' In a way, that's a game too. You have a challenge, and you have a narrative, drama... and the substitute teachers are sitting next to me and staring at me like I'm crazy. [laughter] And then the students get to work for 45 minutes. [Primary school teacher]

The activity itself (having students research a topic) was nothing new; it was something all teachers do. However, with small adjustments, it can be made a playful task through the teacher's playful stance towards his/her teaching practices.

\subsubsection{Ability to explore and improvise}

Another closely related point is a readiness to iteratively explore and improvise: to experiment with new tools and methods without worrying about failure, to 'jump into the unknown' with students and improvise on the go to seek activities which feel natural and motivating to teacher and students alike. In many excerpts, teachers mention that it is fun and motivating to try new things and see where they lead, and if the experimentations are successful, these tools and methods become established practices. For some teachers competencies related to exploration came naturally due to their personal interests (Excerpt 13). However, others developed them by experimenting with small steps at a pace they were comfortable with. 
(13) And I guess it's [partly because] I was always the geek of the class myself and always liked to make things like role-playing games when I was a young boy, so it somehow feels like a natural part [of the job] that you just start exploring, doing and looking for motivating ways to teach. [Primary school teacher]

Finally, the teachers also described situations where their original plan did not work as expected and they had to react flexibly and adjust the pedagogical idea of the activity on the go. This necessitated improvisation skills.

\subsubsection{Creative orientation to self-development}

Teachers also highlighted the readiness to continuously develop their competencies in GBP and reflect on and reshape their teacher identity. We refer to this as creative orientation to self-development. Teachers felt that GBP challenged them to rethink and enhance their practices in order to find pedagogically meaningful ways to use games. This was also experienced as motivating. In Excerpt 14, a teacher discusses how implementing role-play-based gamification enhanced his own competencies which, in turn, will benefit his students.

(14) It's been fun to take up a broader... um, to experiment again with a bit more different thing. And that has indeed brought a great deal of value to this work, like, you want to develop yourself and take your own professional competence further, and then, in a way, to use this professional competence for the good of the students. [Primary school teacher]

To sum up, we will next present how the four competence areas manifested in the teacher's activities during a game-based learning process in one of the participating schools.

\subsection{Concluding Example Case}

To further illustrate our results, we can look at one of our research cases (see Excerpts 1, 5 and 14) in light of the four competence areas. In this case, a teacher implemented gamified projects with sixthgraders, teaching history and geography through a role-play context where various game-based tools and approaches were utilised. This required, for example, competencies to transform curricular contents - in this case, the Middle Ages and European countries - into relevant game-based objectives (Pedagogical area: Curriculum-based planning). In the learning process, the students were allowed to participate actively from orientation to elaboration (cf. Figure 2). Before the play, they did research so that they could develop their own characters (i.e. orientation). During the activities (i.e. creation and play), they had plenty of freedom within the general objectives of the activity, which led to the emergence of teachable moments such as spontaneous in-game trading that provided an opportunity to discuss the medieval economic and social structures (Pedagogical area: Tutoring). The teacher recognised a need to establish more checkpoints along the process to facilitate assessment (Pedagogical area: Assessment) and collected student feedback to evaluate the whole role-play activity (i.e. elaboration). Understanding the affordances of different games and tools for addressing said objectives was also important: when designing and implementing the activity, the teacher combined various existing games and applications with non-digital role-play elements (Technological area: Analysing 
games and tools). In this research case, the collaborative area manifested as increased competencies in implementing GBP leading to plans of a joint role-play project with other schools (Collaborative area: Networking and collaboration beyond the school). This was also closely intertwined with the creative area, enhancing the teacher's own motivation to develop new innovative approaches (Creative area: Creative orientation to self-development).

\section{Conclusion and Discussion}

This study focused on competencies teachers found necessary in implementing GBP. The findings highlight four competence areas (pedagogical, technological, collaborative and creative) manifested in the GBP processes implemented in the schools. In this section, we will discuss our results in light of our conceptual and pedagogical framework and reflect on the potential of the results for supporting the development of teacher competencies that are in line with curricular objectives. Furthermore, we will discuss the limitations of the study, implications of the results for teacher training and ideas for further research.

\subsection{Reflecting on Competence Areas}

Game-based learning necessitates careful coordination of various knowledge domains (Bourgonjon et al., 2013), and our results show that implementing GBP requires diverse teacher competencies. Figure 3 summarises how the four competence areas identified in this study are emphasised in different phases of our conceptual and pedagogical framework (presented in Figure 2).

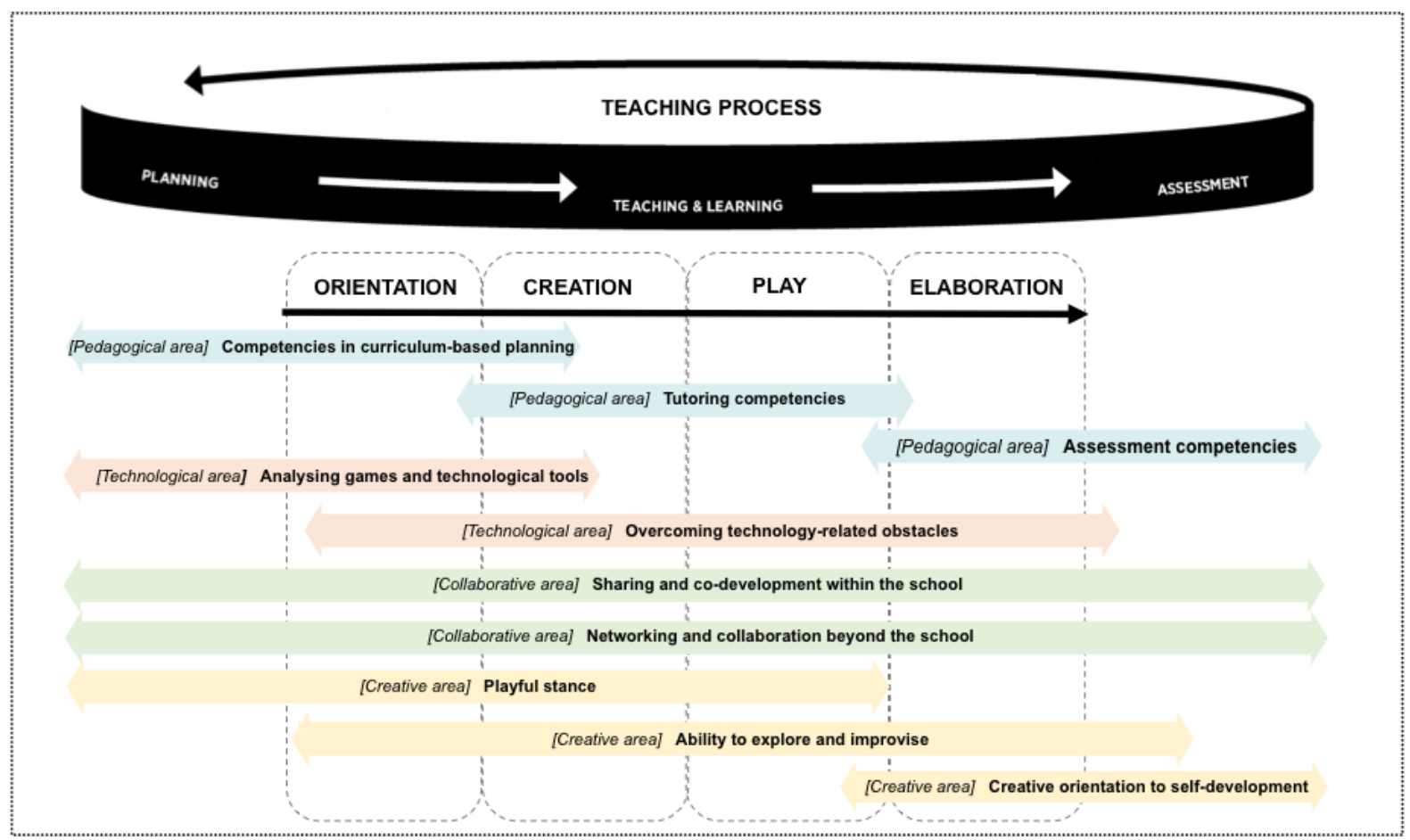

Figure 3. Competencies mapped with the conceptual and pedagogical framework. 
As Figure 3 illustrates, pedagogical competence areas cover all phases in playful, game-based learning. The results suggest that whatever GBP approach is chosen, a pedagogically competent teacher can plan, implement and assess game-based learning activities and connect them meaningfully with the curriculum (cf. Foster, Shah, \& Duvall, 2016). Planning competencies are emphasised when the teacher initially designs the process and when teacher and students together orient to the activities. For instance, a pedagogically competent teacher has the means to engage students in planning and designing the forthcoming play and learning activities, methods and (digital) tools. Tutoring competencies correspond to necessary guiding during actual game-based activities (i.e. creation and play). These competencies can refer, for example, to abilities to acknowledge so-called teachable moments — interactional situations where the teacher tutors students' learning process to deepen their understanding of the topic and proceeding in the game (Watson et al., 2011). Assessment competencies refer both to assessing students' learning outcomes and reflecting on the process with them (i.e. elaboration).

Regarding technological competencies, skills related to analysing games and technological tools are especially emphasised before and at the beginning of the process, while during the activity, competencies related to overcoming technology-related obstacles emerge as crucial (Figure 3). In practice, technological competencies include the ability to select and combine appropriate games and tools (cf. Shah \& Foster, 2015) and see students' and colleagues' expertise as resources in using technologies and overcoming obstacles (cf. Cachia, Ferrari, Ala-Mutka, \& Punie, 2010). Technologically competent teachers also understand specific games and digital tools as flexible learning environments to adapt to players' knowledge and skill levels. The results reflect recent empirical findings that teachers need technological knowledge of how to use digital games (Foster et al., 2016) and other playful, game-based learning approaches inside and outside classroom settings (Kangas, 2010a). An important question is how teachers see technological problems and challenges - as possibilities, obstacles or non-existent. Earlier research has shown that when teachers engage in the pedagogical approach, they have a sense of confidence (Smith \& Strahan, 2004) and can solve new problems (Bransford, Brown, \& Cocking, 1999). In the digital context, openness towards technology and digital self-efficacy positively influence the use of game-based learning technologies (Hamari \& Nousiainen, 2015), and when teachers' comfort and competence are relatively high, they might start designing new, creative, student-centred ways to utilise technology (Rikala, Hiltunen, \& Vesisenaho, 2014).

The results indicate that teachers benefit from a range of collaborative competencies when implementing GBP; these may relate to teamwork within the same school or networking with teachers from other schools and other relevant actors. Collaborative competencies seem to be less clearly linked with specific parts of the GBP process; they may be required when planning activities with other teachers, implementing a joint project or sharing and reflecting on experiences with others (Figure 3 ). Collaboration is important because it nurtures novel approaches to GBP. Innovative teaching flourishes when the school culture is collaborative and supportive in terms of peer support and sharing, direct involvement of teachers in practicing new teaching methods and a common vision encouraging novel approaches (Shear, Gallagher, \& Patel, 2011). Social influences and the encouragement of the local environment also affect how useful teachers perceive games to be in their work (Bourgonjon et al., 2013; Ketelhut \& Schifter, 2011). In our results, this manifested in accounts of how pedagogical practices, knowledge about games and technological know-how spread from more experienced teachers to others, especially through implementing something concrete together. For instance, teachers may plan, implement and assess a joint game-based learning process in several schools. This kind of codevelopment and collaboration can provide teachers with opportunities to identify and link tacit 
knowledge for completely new openings and ideas (cf. Dillon, Wang, Vesisenaho, Valtonen, \& HavuNuutinen, 2013).

Finally, the creative competence area was evident in the teachers' reflections. The findings indicate that to use GBP successfully, it is critical that teachers express a playful stance of exploring, improvising and innovating, motivated to learn and leave their comfort zone. The need for a playful stance manifests throughout the process but is emphasised particularly when planning and conducting learning activities, while willingness to explore and improvise is required especially during the learning activities (Figure 3). The third sub-area, creative orientation to self-development, is emphasised when reflecting on what the game-based activities have taught teachers about their competencies and how this may affect their teacher identity (Figure 3). Teachers who express pedagogical and emotional engagement also apply playful learning creatively and exhibit personal entrepreneurship skills (Kangas et al., 2017) and are thus often eager to know how novel teaching and learning methods work (Sawyer, 2012).

We can also look at the GBP competencies through the lens of knowledge, skills and attitudes (Binkley et al., 2012; Tigelaar et al., 2004; see Section 2.2). For example, competencies in the pedagogical area are based on teachers' theoretical knowledge of planning, carrying out and assessing the learning process; when applied to the game-based process, these become practical skills. Conversely, while technological competencies also require background knowledge, they are often principally developed through hands-on activities, their starting point within the dimension of practical skills. Furthermore, in the collaborative and creative areas, the attitude dimension is emphasised. Our results imply that the teachers believe personal stance (including attributes such as openness, persistence and willingness to explore, share and learn from mistakes; Binkley et al., 2012) often is significant in the extent to which these two areas manifest in their work. Thus, knowledge and skills are just the tip of the iceberg (Spencer \& Spencer, 1993). Even if teachers have up-to-date technology, knowledge and support, they may not be enthusiastic enough to use technology and games in class (Mumtaz, 2000). Hence, other dimensions underlie and affect technology and game usage (Ertmer, 1999).

Teacher competencies are increasingly important and interesting for both research and policy development, with many related efforts currently ongoing. In parallel with our study, for example, the European Commission (Redecker, 2017) has been developing DigCompEdu, a framework for assessing educators' digital competencies. Several competencies in the DigCompEdu framework also correspond to those identified in this study in the game-based pedagogical context. Thus, it is important to consider possible synergies between different frameworks and tools. Existing assessment frameworks can be applied in different contexts, including GBP, to support teachers' self-reflection on their competencies.

In twenty-first century education, teachers are expected to use relevant methods and digital tools to engage learners and promote their key competencies (cf. Binkley et al., 2012). For example, the new Finnish core curriculum seeks to change the approach from what to teach to how to teach, thus connecting the goals of key competencies to more specific learning objectives (Vitikka, Krokfors, \& Rikabi, 2016). In addition, the curriculum emphasises the role of play and games as learning methods, tools and environments and encourages teachers to use play, games and playfulness in teaching in multiple ways. The game-based approaches and the conceptual and pedagogical framework presented in this study may provide teachers tools for reflecting on and developing GBP in their own work so that their teaching is in line with school education curricula and correspond with the requirements of the digitalised society. 


\subsection{Limitations and Implications}

Like all studies, this study has some limitations. One was the constitution of the sample; 1) the number of teachers participating was limited; 2) the study concentrated on Finnish schools and teachers (particularly participants in a specific networking project focusing on developing GBP in certain schools); and 3) the responses depended on the teachers' willingness to honestly and reliably recall and report their game-based pedagogies and experiences. Nevertheless, the objective was to reach conceptions and understanding of teacher competencies in GBP; thus, even though the data may be specific to particular schools and teachers, the explanations and conclusions can be useful in understanding how other schools or teachers work (Aaltio \& Heilmann, 2010; Gillham, 2010). The study focused on basic education, and while the competence areas can be seen as applicable to other educational contexts as well, the original context is likely to have influenced the emphasis of some aspects within the areas.

Teacher education in GBP is still in its infancy and needs a comprehensive approach to develop teachers' competence (Foster et al., 2015). Therefore, this study makes important contributions. The results are applicable for acknowledging competence areas needed in GBP and developing teacher education and in-service training, as teacher competencies in game-based learning will be more integral to teachers' professional knowledge and skill repertoires. This means, for example, developing teacher education curricula and providing courses focusing on pedagogical aspects of using play, games and gamification in teaching and learning. We also argue that the debate on teacher competencies in parallel with renewed curricula is important in order to focus more on increasing teachers' competence areas in terms of GBP. It is also notable that today there are several forums available for teachers to develop their competencies, such as national in-service training projects and informal social media networks. The competence areas together with the pedagogical and conceptual framework can serve as a tool both for individual teachers and teacher trainers in defining focus areas for competence development.

This study was conducted in a data-driven way to identify the most relevant competencies. One potential future research topic is to delve deeper into the relationship between competence areas and game-based approaches and examine more closely how different competencies manifest when using educational games, entertainment games, game-making and gamification. Also, as the present study was conducted during an ongoing networking project, it will be important to investigate development of game-based pedagogical competencies in a more sustainable context, addressing, for example, teachers' experiences with aspects which have fostered or hindered the development of these competencies in the longer term.

\section{Acknowledgements}

The authors would like to thank all the teachers who participated in the research. The data were collected during the project 'Game-based Pedagogy and Portfolio-based Learning' coordinated by the City of Helsinki Education Department and funded by The Finnish National Board of Education between the years 2013 and 2016. 


\section{References}

Aaltio, I., \& Heilmann, P. (2010). Case study as a methodological approach. In A. J. Mills, G.

Durepos, \& E. Wiebe (Eds.), Encyclopedia of Case Study Research (pp. 67-78). Thousand Oaks:

SAGE Publications.

Allsop, Y., \& Jessel, J. (2015). Teachers' experience and reflections on game-based learning in the primary classroom: Views from England and Italy. International Journal of Game-Based Learning, $5(1), 1-17$.

Amabile, T. (1983). The social psychology of creativity. New York: Springer-Verlag.

Barab, S. A., Gresalfi, M., \& Ingram-Goble, A. (2010). Transformational play: Using games to position person, content, and context. Educational Researcher, 39(7), 525-536.

Bateson, P., \& Martin, P. (2013). Play, playfulness and innovation. New York: Cambridge University Press.

Binkley, M., Erstad, O., Herman, J., Raizen, S., Ripley, M., Miller-Ricci, M., \& Rumble, M. (2012). Defining twenty-first century skills. In P. Griffin, B. McGaw, \& E. Care (Eds.), Assessment and teaching of 21st century skills (pp. 17-66). Dordrecht: Springer.

Bjarnadottir, R. (2005, September). The struggle with own person: The personal aspect in teacher competence experienced by teacher students. Paper presented at the European Conference on Educational Research, Dublin. Retrieved on March 14, 2018 from:

http://www.leeds.ac.uk/educol/documents/143770.htm

Bourgonjon, J., De Grove, F., De Smet, C., Van Looy, J., Soetaert, R, \& Valcke, M. (2013). Acceptance of game-based learning by secondary school teachers. Computers \& Education, 67, 2135 .

Bransford, J. D., Brown, A. L., \& Cocking, R. R. (1999). How people learn: Brain, mind, experience, and school. Washington, DC: National Academy Press.

Cachia, R., Ferrari, A., Ala-Mutka, K., \& Punie, Y. (2010). Creative learning and innovative teaching: Final report on the study on creativity and innovation in education in the EU member states. Luxembourg: Publications Office of the European Union.

Caena, F. (2014). Teacher competence frameworks in Europe: Policy-as-discourse and policy-aspractice. European Journal of Education, 49(3), 311-331.

Charsky, D., \& Mims, C. (2008). Integrating commercial off-the-shelf video games into school curriculums. Tech Trends: Linking Research and Practice to Improve Learning, 52(5), 38-44.

Chee, Y. S., \& Tan, K. C. D. (2012). Becoming chemists through game-based inquiry learning: The case of Legends of Alkhemia. Electronic Journal of e-Learning, 10(2), 185-198.

Corredor, J., Gaydos, M., \& Squire, K. (2014). Seeing change in time: Video games to teach about temporal change in scientific phenomena. Journal of Science Education and Technology, 23(3), 324343. 
Csikszentmihalyi, M. (1993). The evolving self: A psychology for the third millennium. New York: Harper Perennial.

De Freitas, S. (2006). Learning in immersive worlds: A review of game-based learning. London: Joint Information Systems Committee. Retrieved on 25 July, 2017 from: https://curve.coventry.ac.uk/open/file/aeedcd86-bc4c-40fe-bfdf-df22ee53a495/1/learning in immersive worlds.pdf

De Grove, F., Bourgonjon, J., \& Van Looy, J. (2012) Digital games in the classroom? A contextual approach to teachers' adoption intention of digital games in formal education. Computers in Human Behavior, 28(6), 2023-2033.

Deterding, S., Dixon, D., Khaled, R., \& Nacke, L. (2011). From game design elements to gamefulness: Defining "gamification". In Proceedings of the 15th International Academic MindTrek Conference: Envisioning Future Media Environments (pp. 9-15). New York: ACM.

Devlin, K. (2011). Mathematics education for a new era: Video games as a medium for learning. Natick: A K Peters Ltd.

Dillon, P., Wang, R. L., Vesisenaho, M., Valtonen, T., \& Havu-Nuutinen, S. (2013). Using technology to open up learning and teaching through improvisation: Case studies with micro-blogs and short message service communications. Thinking Skills and Creativity, 10, 13-22.

Domínguez, A., Saenz-de-Navarrete, J., de-Marcos, L., Fernández-Sanz, L., Pagés, C., \& MartínezHerráiz, J.-J. (2013). Gamifying learning experiences: Practical implications and outcomes. Computers \& Education, 63, 380-392.

Dondi, C., \& Moretti, M. (2007). A methodological proposal for learning games selection and quality assessment. British Journal of Educational Technology, 38(3), 502-512.

Egenfeldt-Nielsen, S. (2005). Beyond edutainment: Exploring the educational potential of computer games (Unpublished doctoral thesis), IT-University of Copenhagen, Denmark.

Egenfeldt-Nielsen, S. (2011). What makes a good learning game? Going beyond edutainment. eLearn Magazine, 2011(2).

Ertmer, P. A. (1999). Addressing first- and second-order barriers to change: Strategies for technology integration. Educational Technology Research and Development, 47(4), 47-61.

European Commission. (2018). Key competences. Retrieved on 14 March, 2018 from: https://ec.europa.eu/education/policy/school/competences en

Farber, M. (2015). Gamify your classroom: A field guide to game-based learning. New York: Peter Lang Publishing.

Ferrari, A. (2013). DIGCOMP: A framework for developing and understanding digital competence in Europe (Y. Punie \& B. N. Brečko, Eds.). Luxembourg: Publications Office of the European Union.

Finnish National Board of Education. (2016). National core curriculum for basic education 2014. Helsinki: Finnish National Board of Education.

Foster, A. N., Shah, M., \& Duvall, M. (2015). Game network analysis: For teaching with games. In 
M. L. Niess, \& H. Gillow-Wiles (Eds.), Handbook of research on teacher education in the digital age (pp. 380-411). Hershey: IGI Global.

Foster, A., \& Shah, M. (2015). The play curricular activity reflection discussion model for gamebased learning. Journal of Research on Technology in Education, 47, 71-88.

Gillham, B. (2010). Case study research methods. London: Continuum International Publishing.

Gresalfi, M., Barnes, J., \& Pettyjohn, P. (2011). Why videogames are not teacher-proof: The central role of the teacher when using new technologies in the classroom. In G. Vincenti, \& J. Braman (Eds.), Multi-user virtual environments for the classroom: Practical approaches to teaching in virtual worlds (pp. 267-284). Hershey, PA: IGI Global.

Hamari, J., \& Nousiainen, T. (2015). Why do teachers use game-based learning technologies? The role of individual and institutional ICT readiness. In Proceedings of the 48th Hawaii international conference on system sciences (pp. 682-691). IEEE.

Hammersley, M., \& Gomm, R. 2000. Introduction. In R. Gomm, M. Hammersley, \& P. Foster (Eds.), Case study method: key issues, key texts (pp. 1-16). London: Sage.

Hanghøj, T. (2011). Clashing and emerging genres: The interplay of knowledge forms in educational gaming. Designs for Learning, 4(1), 22-33.

Hanghøj, T. (2013). Game-based teaching: Practices, roles, and pedagogies. In S. Freitas, M. Ott, M. M. Popescu, \& I. Stanescu (Eds.), New pedagogical approaches in game enhanced learning. Curriculum interaction (pp. 81-101). Hershey, PA: IGI Global.

Hanghøj, T., \& Brund, C. E. (2011). Teachers and serious games: Teachers roles and positionings in relation to educational games. In S. Egenfeldt-Nielsen, B. Meyer, \& B. H. Sørensen (Eds.), Serious games in education: A global perspective (pp. 125-136). Aarhus: Aarhus Universitetsforlag.

Hayes, E. R., \& Games, A. (2008). Making computer games and design thinking: A review of current software and strategies. Games and Culture, 3, 3-4.

Hsu, C.-Y., Tsai, M.-J., Chang, Y.-H., \& Liang, J.-C. (2017). Surveying in-service teachers' beliefs about game-based learning and perceptions of technological pedagogical and content knowledge of games. Educational Technology \& Society, 20(1), 134-143.

Hwang, G. J., \& Wu, P. H. (2012). Advancements and trends in digital game-based learning research: A review of publications in selected journals from 2001 to 2010. British Journal of Educational Technology, 43(1), E6-E10.

Hämäläinen, R., \& Oksanen, K. (2014). Collaborative 3D learning games for future learning: Teachers' instructional practices to enhance shared knowledge construction among students. Technology, Pedagogy and Education, 23(1), 81-101.

Johannesen, M., Øgrim, L., \& Giæver, T. H. (2014). Notion in motion: Teachers' digital competence. Nordic Journal of Digital Literacy, 9, 300-312.

Kafai, Y. (2006). Playing and making games for learning: Instructionist and constructionist perspectives for game studies. Games and Culture, 1(1), 36-40. 
Kafai, Y., \& Resnick, M. (1996). Constructionism in practice: Designing, thinking and learning in a digital world. Mahwah, NJ: Lawrence Erlbaum Associates.

Kangas, M. (2010a). Creative and playful learning: Learning through game co-creation and game play in a playful learning environment. Thinking Skills and Creativity, 5(1), 1-15.

Kangas, M. (2010b). The school of the future: Theoretical and pedagogical approaches for creative and playful learning environments. Doctoral dissertation. Rovaniemi: University of Lapland Printing Centre. Acta Universitatis Lapponiensis 188. University of Lapland, Faculty of Education, Finland.

Kangas, M., Koskinen, A., \& Krokfors, L. (2016). A qualitative literature review of educational games in the classroom: The teacher's pedagogical activities. Teachers and Teaching: Theory and Practice, 23(4), 451-470.

Kangas, M., Siklander, P., Randolph, J., \& Ruokamo, H. (2017). Teachers' engagement and students' satisfaction with the playful learning environment. Teaching and Teacher Education, 63, 274-284.

Kapp, K. M. (2012). The gamification of learning and Instruction: Case-based methods and strategies for training and education. New York: Pfeiffer.

Kebritchi, M., Hirumi, A., \& Bai, H. (2010). The effects of modern mathematics computer games on mathematics achievement and class motivation. Computers \& Education, 55(2), 427-443.

Ketelhut, D. J., \& Schifter, C. C. (2011). Teachers and game-based learning: Improving understanding of how to increase efficacy of adoption. Computers \& Education, 56(2), 539-546.

Koehler, M. J., \& Mishra, P. (2009). What is technological pedagogical content knowledge? Contemporary Issues in Technology and Teacher Education, 9(1), 60-70.

Krokfors, L., Kangas, M., \& Kopisto, K. (2014). Pedagogiset mallit peleissä ja peleistä oppimisen tukena [Pedagogical models in games and supporting game-based learning]. In L. Krokfors, M. Kangas, \& K. Kopisto (Eds.), Oppiminen pelissä. Pelit, pelillisyys ja leikillisyys opetuksessa. [Learning in games. Games, gamefulness and playfulness in education] (pp. 208-219). Tampere: Vastapaino.

Lee, J. J., \& Hammer, J. (2011). Gamification in education: What, how, why bother? Academic Exchange Quarterly, 15(2).

Löfström, E., \& Nevgi, A. (2007). From strategic planning to meaningful learning: Diverse perspectives on the development of web-based teaching and learning in higher education. British Journal of Educational Technology, 38(2), 312-324.

Meyer, B., \& Holm Sørensen, B. (2011). Methods and design for research in global oriented gamebased language learning. In M. S. Khine (Ed.), Playful teaching, learning games: New tool for digital classrooms (pp. 51-64). Rotterdam: Sense Publishers.

Mumtaz, S. (2000). Factors affecting teachers' use of information and communications technology: A review of the literature. Journal of Information Technology for Teacher Education, 9(3), 319-342.

Nousiainen, T., Vesisenaho, M., \& Eskelinen, P. (2015). 'Let's do this together and see what we can come up with!': Teachers' views on applying game-based pedagogy in meaningful ways. eLearning Papers, 2015(44), 74-84. 
Pelletier, C., Burn, A., \& Buckingham, D. (2010). Design as textual poaching: Media literacy, creativity and game-making. E-Learning and Digital Media, 7(1), 90-107.

Randolph, J., Kangas, M., Ruokamo, H., \& Hyvönen, P. (2016). Creative and playful learning on technology-enriched playgrounds: an international investigation. Interactive Learning Environments, 24(3), 409-422. Published online in 2013.

Redecker, C. (2017). European framework for the digital competence of educators:

DigCompEdu (Y. Punie, Ed.). Luxembourg: Publications Office of the European Union.

Resnick, M. (2006). Computer as paintbrush: Technology, play, and the creative society. In D. Singer, R. Golikoff, \& K. Hirsh-Pasek (Eds.), Play = learning: How play motivates and enhances children's cognitive and social-emotional growth (pp. 192-208). Oxford: Oxford University Press.

Richardson, U., \& Lyytinen, H. (2014). The GraphoGame method: The theoretical and methodological background of the technology-enhanced learning environment for learning to read. Human Technology, 10(1), 39-60.

Rikala, J. (2015). Designing a mobile learning framework for a formal educational context. Doctoral dissertation. Finland: University of Jyväskylä. Jyväskylä studies in computing, 220. Jyväskylä.

Rikala, J., Hiltunen, L., \& Vesisenaho, M. (2014). Teachers' attitudes, competencies, and readiness to adopt mobile learning approaches. In Proceedings of 2014 IEEE Frontiers in Education Conference (pp. 2529-2536). IEEE.

Robertson, J. (2012). Making games in the classroom: Benefits and gender concerns. Computers \& Education, 59(2), 385-398.

Ronimus, M., Kujala, J., Tolvanen, A., \& Lyytinen, H. (2014). Children's engagement during digital game-based learning of reading: The effects of time, rewards, and challenge. Computers \& Education, $71,237-246$.

Sawyer, K. (2012). Extending sociocultural theory to group creativity. Vocations and Learning, 5(1), $59-75$.

Shah, M., \& Foster, A. (2015). Developing and assessing teachers' knowledge of game-based learning. Journal of Technology and Teacher Education, 23(2), 241-267.

Shear, L., Gallagher, L,. \& Patel, D. (2011). ITL Research 2011 findings: Evolving educational ecosystems. Menlo Park, CA: SRI International.

Shin, N., Sutherland, L. M., Norris, C. A., \& Soloway, E. (2012). Effects of game technology on elementary student learning in mathematics. British Journal of Educational Technology, 43(4), 540560.

Smith, T. W., \& Strahan, D. (2004). Toward a prototype of expertise in teaching: A descriptive case study. Journal of Teacher Education, 55(4), 357-371.

Spencer, L., \& Spencer, S. (1993). Competence at work: Models for superior performance. New York: John Wiley \& Sons. 
Squire, K. D., \& Jan, M. (2007). Mad City Mystery: Developing scientific argumentation skills with a place-based augmented reality game on handheld computers. Journal of Science Education and Technology, 16(1), 5-29.

Stenroos, J. (2015). Playfulness, play, and games: A constructionist ludology approach (Doctoral dissertation, University of Tampere, Finland). Retrieved on 14 March, 2018 from:

http://urn.fi/URN:ISBN:978-951-44-9788-9

Sørensen, B. H. (2011). Educational design for serious games. In S. Egenfeldt-Nielsen, B. Meyer, \& B. H. Sørensen (Eds.), Serious games in education - A global perspective (pp. 101-121). Aarhus: Aarhus University Press.

Tigelaar, D., Dolmans, D., Wolfhagen, I.. \& Van Der Vleuten, C. (2004). The development and validation of a framework for teaching competencies in higher education. Higher Education, 48(2), 253-268.

UNESCO [United Nations Educational, Scientific and Cultural Organization]. (2011). UNESCO ICT Competency Framework for Teachers. Retrieved on 14 March, 2018 from: http://unesdoc.unesco.org/images/0021/002134/213475e.pdf

Van Eck, R. (2006). Digital game-based learning: It's not just the digital natives who are restless. EDUCAUSE Review, 41(2), 16-18.

Vitikka, E., Krokfors, L., \& Rikabi, L. (2016). The Finnish national core curriculum: Design and development. In H. Niemi, A. Toom, \& A. Kallioniemi (Eds.), Miracle of education: The principles and practices of teaching and learning (pp. 83-90). Rotterdam: Sense Publishers.

Vos, N., van der Meijden, H., \& Denessen, E. (2011). Effects of constructing versus playing an educational game on student motivation and deep learning strategy use. Computers \& Education, 56(1), 127-137.

Watson, W. R., Mong, C. J., \& Harris, C. A. (2011). A case study of the in-class use of a video game for teaching high school history. Computers \& Education, 56(2), 466-474.

Williamson, B. (2009). Computer games, schools and young people: A report for educators on using games for learning. Bristol: Futurelab. Retrieved on 14 March, 2018 from: https://www.nfer.ac.uk/publications/FUTL27/FUTL27.pdf

Yang, Y.-T. C., \& Chang, C.-H. (2013). Empowering students through digital game authorship: Enhancing concentration, critical thinking, and academic achievement. Computers \& Education, 68 , 334-344.

Yin, R. K. (2003). Case study research: Design and methods (3rd ed.). Thousand Oaks, CA: Sage.

Young, M. F., Slota, S., Cutter, A. B., Jalette, G., Mullin, G., Lai, B., Simeoni, Z., Tran, M., \& Yukhymenko, M. (2012). Our princess is in another castle: A review of trends in serious gaming for education. Review of Educational Research, 82(1), 61-89. 


\section{Appendix}

Interview themes and open-ended questions form the questionnaires

\begin{tabular}{|c|c|}
\hline Instrument & Themes or questions \\
\hline Interview & $\begin{array}{l}\text { Background information (school, teachers, grades, subjects) } \\
\text { Description of the GBP activities (methods, tools, practices, activities; extent of } \\
\text { activities; subjects in which GBP was implemented) } \\
\text { Teachers' experiences (expectations and goals; added value for teacher; } \\
\text { particularly successful experiences; challenges and problems; what the teachers } \\
\text { would do differently) } \\
\text { Teachers' observations on students' work with GBP (direct or indirect feedback } \\
\text { from students; observations on students' work; added value for students) } \\
\text { Motivational aspects of GBP (how different motivational factors manifested in } \\
\text { GBP in practice; how game-based elements were used to promote motivation) } \\
\text { Role of GBP for promoting learning (the effects of games for learning subject- } \\
\text { specific skills and broader key competencies; the role of games in assessment) } \\
\text { Sustainability of GBP in the school's educational practice (experiences obtained } \\
\text { during the project; plans for continuing and spreading the competencies; aspects } \\
\text { potentially hindering the sustainability of GBP) }\end{array}$ \\
\hline $\begin{array}{l}\text { Questionnaire } \\
\text { (2014) }\end{array}$ & $\begin{array}{l}\text { Please describe briefly one or more particularly positive experiences related to } \\
\text { implementing game-based pedagogy. } \\
\text { Please describe briefly one or more particularly challenging or problematic } \\
\text { experiences related to implementing game-based pedagogy. } \\
\text { General comments or feedback related to the project. }\end{array}$ \\
\hline $\begin{array}{l}\text { Questionnaire } \\
\text { (2016) }\end{array}$ & $\begin{array}{l}\text { Compared to the baseline at the beginning of the project, how has the } \\
\text { implementation of game-based pedagogy developed on the school level and/or } \\
\text { in your own work? Please describe briefly. } \\
\text { In your opinion, what is the potential contribution of game-based pedagogy with } \\
\text { respect to the objectives of the new core curriculum? If possible, please mention } \\
\text { some concrete examples based on the experiences obtained during the project. } \\
\text { How can game-based pedagogy contribute to the assessment of learning? If } \\
\text { possible, please mention some concrete examples based on the experiences } \\
\text { obtained during the project. }\end{array}$ \\
\hline
\end{tabular}

